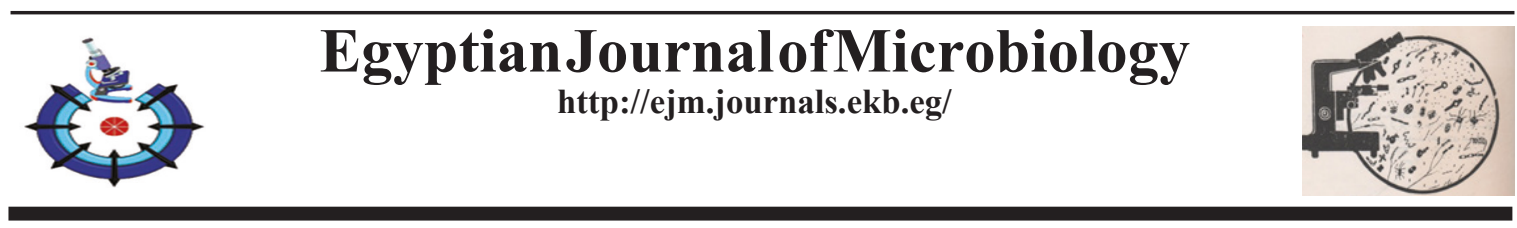

\title{
Statistical Optimization of Industrially Potent Streptomyces plicatus MK559563 Xylanase and $\alpha$-Amylase Production Utilizing Agricultural Wastes
}

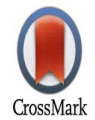

\author{
Shaimaa Kh. Amer ${ }^{(1) \#}$, Faten A. Mostafa ${ }^{(2)}$ \\ (1) Microbiology Department, Faculty of Science, Ain Shams University, Cairo, Egypt; \\ ${ }^{(2)}$ Chemistry of Natural and Microbial Products Department, National Research \\ Centre, Dokki, Giza, 12622, Egypt.
}

\begin{abstract}
QOIL isolate Streptomyces plicatus MK559563 succeeded in the biological conversion

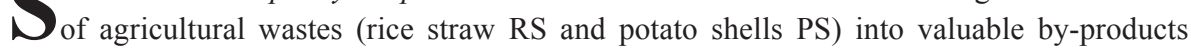
(reducing sugar and industrial enzymes) by sub merged fermentation technique (SmF). Streptomyces plicatus MK559563 xylanase and $\alpha$-amylase production were statistically optimized through two designs Plackett-Burman (PB) and Central composite design (CCD). PB design showed that xylanase production by S. plicatus MK559563 was more affected by incubation time, PS weight, and $\left(\mathrm{NH}_{4}\right)_{2} \mathrm{SO}_{4}$ while $\alpha$-amylase production was more affected by RS weight, $\left(\mathrm{NH}_{4}\right)_{2} \mathrm{SO}_{4}$, and $\mathrm{CaCl}_{2}$. CCD improved $S$. plicatus MK559563 xylanase and $\alpha$-amylase production by 39.69 and $61.60-$ fold increase compared to unoptimized media. The optimized media for $S$. plicatus MK559563 xylanase production composed of g/L: Baker's yeast (1), $\left(\mathrm{NH}_{4}\right)_{2} \mathrm{SO}_{4}(6.5), \mathrm{KCl}(1), \mathrm{ZnSO}_{4}(0.001)$ with $\mathrm{RS}$ (2g/flask) and PS (3.5g/flask) for 7 days of incubation. The optimized media for S. plicatus MK559563 $\alpha$-amylase production composed of g/L: glucose (10), baker's yeast (5), $\left(\mathrm{NH}_{4}\right)_{2} \mathrm{SO}_{4}(6.5), \mathrm{CaCl}_{2}(6.5)$ with $\mathrm{RS}(3.5 \mathrm{~g} /$ flask) and PS (1g/flask) for 6 days of incubation. Streptomyces plicatus MK559563 can be used as an intermediate step for bioconversion of agricultural wastes into biofuel.
\end{abstract}

Keywords: $\alpha$-amylase, Agricultural wastes, Statistical factorial design, Streptomyces sp., Xylanase.

\section{Introduction}

The continuous and rapid progress in the industrial field led to, first: The accumulation of agro-industrial wastes which accordingly caused serious environmental pollution and their disposal requires high costs, second: The requirement of huge quantities of cheap resources for fuel and industrial enzymes. Therefore, all the efforts are directed today to solve these obstacles by, utilizing the agro-industrial wastes for the production of valuable by-products. Since, Agroindustrial wastes are rich in polymers as lignin, cellulose, hemicelluloses (main xylan), pectin. Moreover, the utilization of microorganisms as tools for the production of industrial enzymes by consumption of agro-industrial wastes as fermentation substrates and this can be achieved by either solid state ferementation (SSF) or sub merged fermentation (SmF) techniques. Enzymes have many applications in industries, such as pharmaceutical, food, drink and textile, leather, and paper industry (Pandey et al., 2000; Sivaramakrishnan et al., 2006).

Hemicelluloses are the second most abundant polysaccharide next to cellulose. Xylan is one of the major components of hemicelluloses found in plant cell walls. Complete xylan degradation requires the combined action of different xylanolytic enzymes. Xylanase (E.C.3.2.1.8) is one of the enzymes used in the biodegradation of xylan. Xylanases have been widely used for clarifying fruit juices and wine (Hang \&

\#Corresponding author email: shaymaa_amer@sci .asu.edu.eg

Faten A. Mostafa email: fatenahmedalimostafa@yahoo.com

Received 14/10/2020; Accepted 18/11/2020

DOI: $10.21608 /$ ejm.2020.46345.1176

C2020 National Information and Documentation Center (NIDOC) 
Woodams, 1997; Bhushan et al., 2008; Das et al., 2008; Diaz et al., 2011; Ahmed et al., 2016), with cellulases in food processing and textile industry (Biely, 1985; Abd El Aty et al., 2018), bleaching in the paper and pulp industry (Daneault et al., 1994; Viikari et al., 1994; Polizeli et al., 2005), and hydrolyzing agricultural waste to produce renewable energy products in the biofuel industry (Verma et al., 2010; Wang et al., 2011). Xylanases are also utilized for the production of rayon, cellophane and several chemicals including cellulose esters (acetates, nitrates, propionates and butyrates) and cellulose ethers (carboxymethyl cellulose and methyl and ethyl cellulose), which are all produced by dissolving pulp and purifying fibers from other carbohydrates (Subramaniyan \& Prema, 2002). The xylose resulting from xylan hydrolysis can be converted into xylitol, a valuable sweetener that has applications in both the pharmaceutical and food industries (Parajó et al., 1998; Soleimani et al., 2006). Microbial xylanases are the preferred catalysts for xylan hydrolysis, due to their high specificity, mild reaction conditions, negligible substrate loss and side product generation.

$\alpha$-amylases are extracellular enzymes that catalyze the hydrolysis of $\alpha-1,4$-glycosidic linkages in starch liberating linear and branched oligosaccharides of varying chain lengths as well as glucose (Sharma \& Satyanarayana, 2013). $\alpha$ amylase fins extensive applications in industries like food, brewing, detergents, paper, textile, and dyeing (Abd El Aty et al., 2018). The enzyme is important from a clinical point of view to diagnose pancreatitis. Microbial amylase is more preferred for industrial purposes due to large scale production at a lower cost and in less time.

Various genera of actinomycetes have been reported to produce a wide array of potential industrial enzymes that can be used in biotechnological applications and biomedical fields (Nawani et al., 2013).

Actinobacteria are well known for their productive activities in nutrient recycling by the degradation of chitin, cellulose, starch, lipids, and complex carbohydrates and flouting them into simple sugars by the secretion of various kinds of hydrolytic enzymes in the rhizosphere (Vurukonda et al., 2018). Genus Streptomyces possess a capacity to produce and secrete a variety of extracellular hydrolytic enzymes (Sathya \& Ushadevi, 2014), so it plays a significant role in the recycling of nutrients and involve in the primary degradation of organic matter in compost and related materials (Sykes \& Skinner, 1973), it is considered as one of the most important bacteria, due to their ability to develop the soil properties as well as producing several extracellular substances (enzymes) as secondary products such as $\alpha$-amylases, cellulases, proteases, chitinases, xylanases and pectinase (Brzezinski et al.,1999; Syed et al., 2009; Mohamed et al., 2013; Mohamed et al., 2014).

Microbial enzyme production is usually done by two possible techniques, solid-state and submerged techniques. Nowadays, the submerged cultivation is more favorable due to the ease of sterilization. Optimization of the medium by changing one independent variable keeping the other factors constant has disadvantages as time-consuming and incapable of detecting the most effective factors (Liu \& Tzeng, 1998). While Statistical experimental designs including Plackett-Burmanand response surface methodologies (RSM) can overcome the disadvantages of the classical method. Therefore, the Plackett-Burman design (Plackett \& Burman, 1946) is a powerful statistical technique has been widely used for detecting the most effective medium components for fermentation optimization (Cui et al., 2010; Periyasamy et al., 2010; Chen et al., 2011; Salihu et al., 2011).

For all the mentioned above, this study focused on the utilization of isolated actinomycetes for the conversion of agro-industrial wastes into industrially valuable byproducts ( $\alpha$-amylase, xylanase, and reducing sugar). Besides, optimizing and investigating the most critical factors affecting the production of $\alpha$-amylase and xylanase by two steps factorial design (PlackettBurman and central composite design).

\section{Materials and Methods}

\section{Collection of soil samples}

Soil samples were collected from El- Boyette village- El-What and were air-dried on the benches for one week. Streptomycete isolates were collected from soil samples by serial dilution method (Hayakawa \& Nonomura, 1987) using starch nitrate medium of the following composition (g/L): starch, 20; $\mathrm{KNO}_{3}, 2 ; \mathrm{K}_{2} \mathrm{HPO}_{4}$, $1 ; \mathrm{MgSO}_{4} \cdot 7 \mathrm{H}_{2} \mathrm{O}, 0.5 ; \mathrm{NaCl}, 0.5 ; \mathrm{CaCO}_{3}, 3 ; \mathrm{FeSO}_{4}$ 
$7 \mathrm{H}_{2} \mathrm{O}, 0.01$; agar, $20.0 .1 \mathrm{ml}$ inoculum of the appropriate dilution was plated on each plate. The plates were incubated at $28^{\circ} \mathrm{C}$ for 7 days. After the incubation period the plates were examined for typical streptomyces colonies. Streptomyces form typical round, small, opaque, compact, frequently pigmented (white, brown, gray pink or other colors) and appear dull looking (Bernard, 2007). Streptomycetes colonies were recognized on the basis of morphological characteristics by light microscopy (G X10). Representative colonies were selected and streaked on new plates of starch nitrate agar medium. Agar plates were inoculated with the strains, incubated at $28^{\circ} \mathrm{C}$ until good growth was observed. The isolates were identified as species belonging to the genus Streptomyces by analyzing their morphological characteristics. The isolates were identified morphologically to the genus level by comparing the morphology of spore bearing hyphae with entire sporechain as described in Bergey's Manual (Locci, 1989).

\section{Waste samples}

Waste samples potato shells (PS), banana peels (BP),and rice straw (RS) were collected, dried in an oven at $50^{\circ} \mathrm{C}$ for $24 \mathrm{hrs}$, grinded in a laboratory grinder to $\sim 0.5 \mathrm{~cm}$ particle size.

Production of xylanase and a-amylase by submerged fermentation (SmF)

The purified streptomycetes slant surface were scratched using purified needle after adding $10 \mathrm{ml}$ pure distilled water in each streptomycete slants then transfer $2 \mathrm{ml}$ from each slant into sterile waste flasks prepared by weighting $2 \mathrm{~g}$ from each dried waste and put them in sterile $250 \mathrm{ml}$ conical flasks containing $50 \mathrm{ml}$ sterile distilled water. All flasks containing wastes were autoclaved at $121^{\circ} \mathrm{C}$ for $20 \mathrm{~min}$. After inoculation, the flasks were incubated in a rotary incubator at $28^{\circ} \mathrm{C}$ for 7 days. At the end of the fermentation period each flask, was filtered and the resulted culture filtrate was centrifuged at $5,000 \mathrm{rpm}$ for $10 \mathrm{~min}$. The supernatant was used as enzymes source.

$\alpha$-amylase assay

This was done according to Sajjad \& Choudhry (2012) by mixing $0.5 \mathrm{ml}$ of clear culture filtrate (crude enzyme) and $0.5 \mathrm{ml}$ of $1 \%$ soluble starch $(0.05 \mathrm{M}$ acetate buffer, $\mathrm{pH} 5.0)$. The mixture was incubated for $20 \mathrm{~min}$ at $40^{\circ} \mathrm{C}$ and the released reducing sugars were determined by the Somogyi method (Somogyi, 1952). One unit of $\alpha$-amylase (U) was defined as the amount of enzyme which librated $1 \mu \mathrm{mol}$ of glucose per min under the assay conditions.

\section{Xylanase assay}

This was done according to Warzywoda et al. (1983) by mixing $0.5 \mathrm{ml}$ of clear culture filtrateand $0.5 \mathrm{ml}$ of $1 \%$ xylan $(0.05 \mathrm{M}$ acetate buffer, $\mathrm{pH}$ 5.00 ) and incubating for $30 \mathrm{~min}$ at $50^{\circ} \mathrm{C}$ followed by measuring the released reducing sugars by Somogyi method (Somogyi, 1952). One unit of xylanase was defined as the amount of enzyme that liberates $1 \mu \mathrm{mol}$ of xylose equivalents per minute under assay conditions.

\section{Molecular identification of streptomyces isolates}

The genomic DNA was extracted from the cultures of streptomycete isolate by using a kit (MicroSeq 500 16S rDNA bacterial identification Kits) according to the manufacturer's instructions. Amplification of 16S rDNA by PCR was done using universal bacterial primer forward $\mathrm{F}$ (5'CGGGCGGTGTGTAC - $3^{\prime}$ ) and reverse R (5'CAGCCGCGGTAATAC $-3^{\prime}$ ) which amplify a $\sim 800$-bp. Amplification was carried out in a final volume of $50 \mu 1$ containing; PCR buffer (1x), Taq DNA polymerase $(2.5 \mathrm{U})$, dNTPs $(4 \mathrm{mM})$, primers $(0.4 \mu \mathrm{M})$, and template DNA (4ng) with 100 bp ladder DNA marker. The thermal cycle (PCR) steps were applied as follows; 5 min initial denaturation at $95^{\circ} \mathrm{C}$, followed by 30 cycles of $1 \mathrm{~min}$ denaturation at $95^{\circ} \mathrm{C}, 1 \mathrm{~min}$ primer annealing at $55^{\circ} \mathrm{C}, 1 \mathrm{~min}$ extension at $72^{\circ} \mathrm{C}$, and a final 10 min extension at $72^{\circ} \mathrm{C}$. The amplified DNA fragment was separated on $1 \%(\mathrm{w} / \mathrm{v})$ agarose gel electrophoresis, using TBE buffer containing ethidium bromide $(1 \mu \mathrm{g} / \mathrm{ml})$. A single $\sim 800 \mathrm{bp}$ DNA fragment was cut and extracted from the gel, using a Core Bio-Gel Extraction Kit. The sequence was determined by the Cinna Gen Company.

Sequence data of partial 16S rDNA were aligned and analyzed for finding the closest homologous bacteria. The 16S rRNA nucleotide sequence was compared to nucleotide databases using the BLASTN program that is available from the National Center for Biotechnology Information (NCBI) and retrieved aligned using GeneDoc software version 2.6.002.

\section{Statistical optimization of xylanase and $\alpha$-amylase production}

Plackett-Burman design (PB)

In this design we investigated the effect 
of eleven factor on xylanase and $\alpha$-amylase production including $\mathrm{A}$ : RS weight (g/flask), B: PS weight (g), C: Incubation time (hrs), D: Glucose, E: Lactose (g/L), F: Baker's yeast (g/L), G: $\left(\mathrm{NH}_{4}\right)_{2} \mathrm{SO}_{4}(\mathrm{~g} / \mathrm{L}), \mathrm{H}: \mathrm{CaCl}_{2}(\mathrm{~g} / \mathrm{L}), \mathrm{J}: \mathrm{KCl}(\mathrm{g} / \mathrm{L})$, $\mathrm{K}: \mathrm{ZnSO}_{4}(\mathrm{~g} / \mathrm{L}), \mathrm{L}: \mathrm{CuSO}_{4}(\mathrm{~g} / \mathrm{L})$. Each of these factors was studied with low level $(-1)$ and high level $(+1)$ resulted in 12 trials. The success of the design was statistically analyzed by (ANOVA).

Central composite design (CCD)

In this design we studied the quantitative effect of the three most effective factors determined from the Plackett-Burman design including, (A) incubation time and (B) PS weight and (C) $\left(\mathrm{NH}_{4}\right)_{2} \mathrm{SO}_{4}$ for xylanase and, (A) RS weight, (B) $\left(\mathrm{NH}_{4}\right)_{2} \mathrm{SO}_{4}$ and $(\mathrm{C}) \mathrm{CaCl}_{2}$ for $\alpha$-amylase. Variables were investigated with five levels, -1.682, -1, 0 and $+1,+1.682$ giving 20 trial. The success of the design was statistically analyzed by ANOVA.

\section{Results and Discussion}

Screening of actinomycetes isolates for xylanase and $\alpha$-amylase production

As shown in Fig. 1, first, there was great variation in the ability of the tested isolates for the production of both enzymes according to the utilized agricultural waste. Second, not all the tested isolated were able to produce both enzymes (xylanase and $\alpha$-amylase), i.e. all the isolates except isolate 11 were able to produce xylanase on all agricultural wastes while only isolate 5 was able to produce both enzymes on
RS. Third, the highest xylanase and $\alpha$-amylase production (1.02 and $0.55 \mathrm{U} / \mathrm{ml}$, respectively) by isolate number 5 . The variation in the ability of tested isolates to utilize the different agricultural wastes for enzyme production may be due to the variation in the availability and percent of xylan and starch in the used agricultural waste.

It can be observed that the highest xylanase and $\alpha$-amylase production were obtained on utilizing rice straw. This may be due to that cereals such as rice and corn have a crystalline structure A, while tubers such as potatoes and cassava have a crystalline structure B which has higher water content and a relatively long chain of amylopectin which makes starch more resistant to enzyme attacks (Puspitasari et al., 2011).

Molecular identification of streptomycete isolates by $16 \mathrm{~S}$ rRNA gene sequence analysis

The amplified DNA products separated on agarose gel electrophoresis revealed a single band of $\sim 800 \mathrm{bp}$. PCR sequences of streptomycete isolate were compared with the other sequenced streptomycetes in the NCBI and the database showed similarity with some sequences of other streptomycetes upon the molecular characterization of $16 \mathrm{~S}$ rDNA gene sequence. The sequence data indicated that isolate 5 showed 99\% similarity with Streptomyces plicatus. The DNA sequences were published in the NCBI databases under the following specific accession numbers MK559563 (Fig. 2).
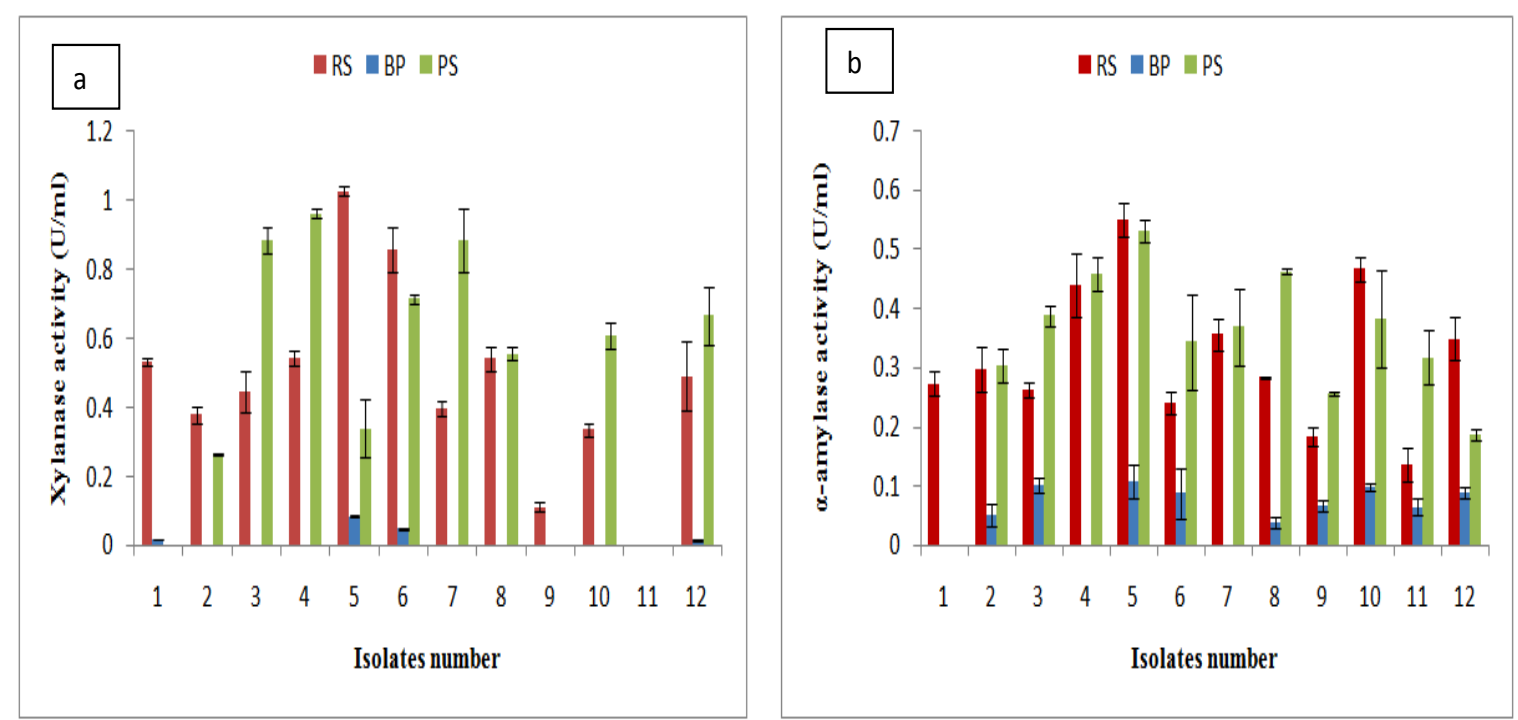

Fig. 1. Screening of different actinomycetes on different agricultural wastes for, a: Xylanase production; b: $\alpha$-amylase production

Egypt. J. Microbiol. 55 (2020) 


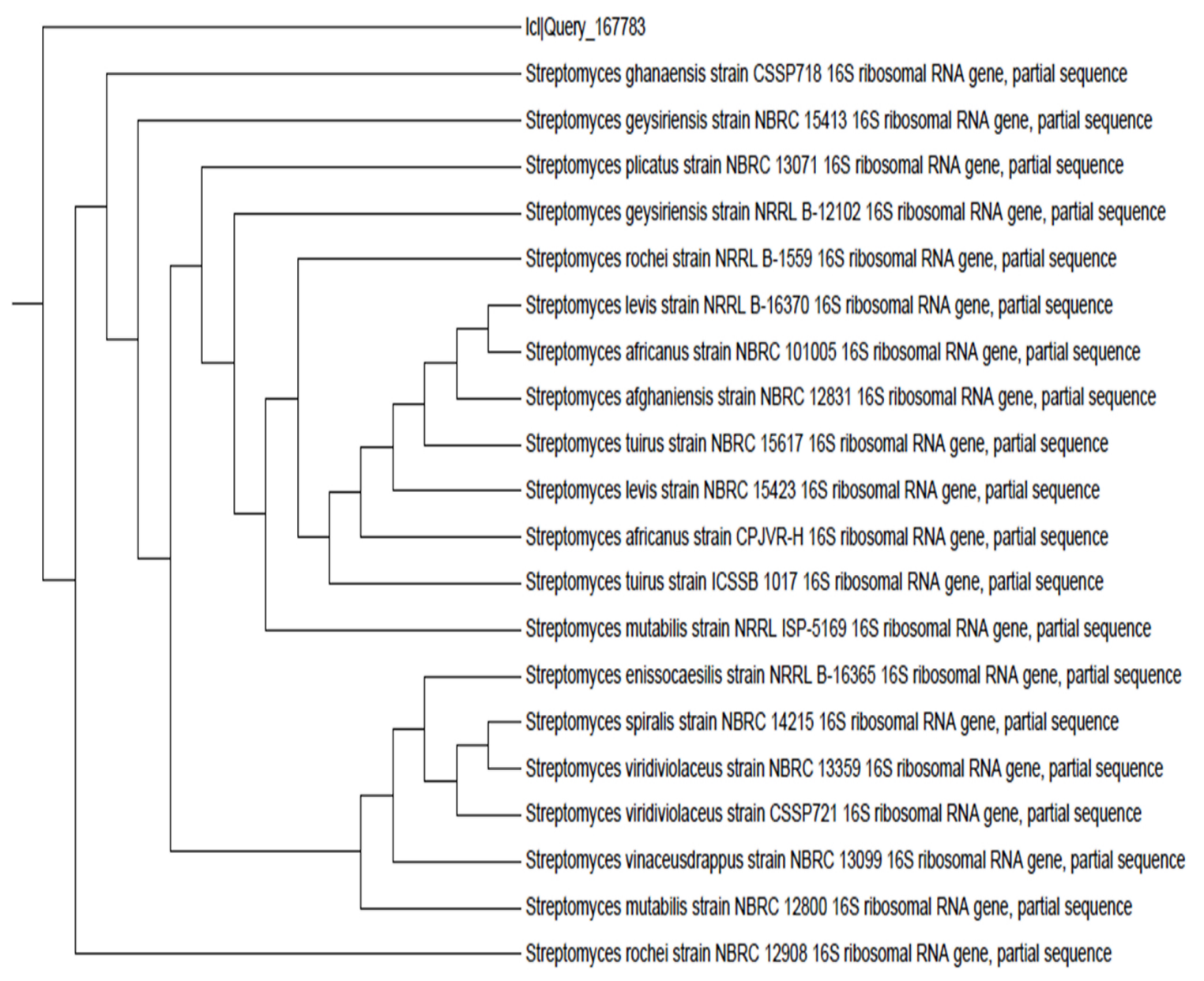

Fig. 2. Phylogenetic tree of Streptomyces plicatus MK559563.

Statistical optimization of S.plicatus MK559563 xylanase and $\alpha$-amylase production

Plackett-Burman design (PB)

In this step as shown in Table 1, the qualitative testing of a different variable resulted in remarkable variation in both enzyme production. i.e. for xylanase and $\alpha$-amylase production, the highest production was obtained in trial 11 $(17.74 \mathrm{U} / \mathrm{ml})$ causing 17.32 -fold increase, and $6(10.71 \mathrm{U} / \mathrm{ml})$ causing 19.49 -fold increase, respectively.

Xylanase and $\alpha$-amylase activitiescan be calculated from the following equations

Xylanase activity $(\mathrm{U} / \mathrm{ml})=+7.21+0.79 *$ PS weight $+4.98 *$ incubation time $-1.38 *$ glucose $-0.58 *$ lactose $+0.86 *\left(\mathrm{NH}_{4}\right)_{2} \mathrm{SO}_{4}-0.81 * \mathrm{CaCl}_{2}$ $+0.22 * \mathrm{KCl}+0.35 * \mathrm{ZnSO}_{4}-0.64 * \mathrm{CuSO}_{4}$

$\alpha$-amylase activity $=+5.92+1.38 * \mathrm{RS}$ weight
$+0.34 *$ PS weight $-0.81 *$ lactose $+0.40 *$ baker's yeast $+0.97 *\left(\mathrm{NH}_{4}\right)_{2} \mathrm{SO}_{4}+0.83 * \mathrm{CaCl}_{2}-0.61$ * $\mathrm{CuSO}_{4}$

From the Pareto chart (Fig. 3a, b) it can be observed that the different variables effect on production differed according to the enzyme. i.e.for xylanase production, it can be observed that among the tested 11 variables only 9 variables exerted significant effect distinguished into 5 positive variables that exerted enhancement effect (incubation time, $\left(\mathrm{NH}_{4}\right)_{2} \mathrm{SO}_{4}$, $\mathrm{PS}$ weight, $\mathrm{ZnSO}_{4}$ and $\mathrm{KCl}$ ) and 4 negative variables (glucose, lactose, $\mathrm{CaCl}_{2}$, and $\mathrm{CuSO}_{4}$ ). Also, the effect of the nutrients differed from microorganism to another. E.g. in our study $\left(\mathrm{NH}_{4}\right)_{2} \mathrm{SO}_{4}$ exerted positive and $\mathrm{CaCl}_{2}$ negative effects on xylanase production similar to that reported by Ali et al. (2016) and in contrast to that reported by Cui \& Zhao (2012) for Penicilliumsp.WX-Z1 xylanase production. 


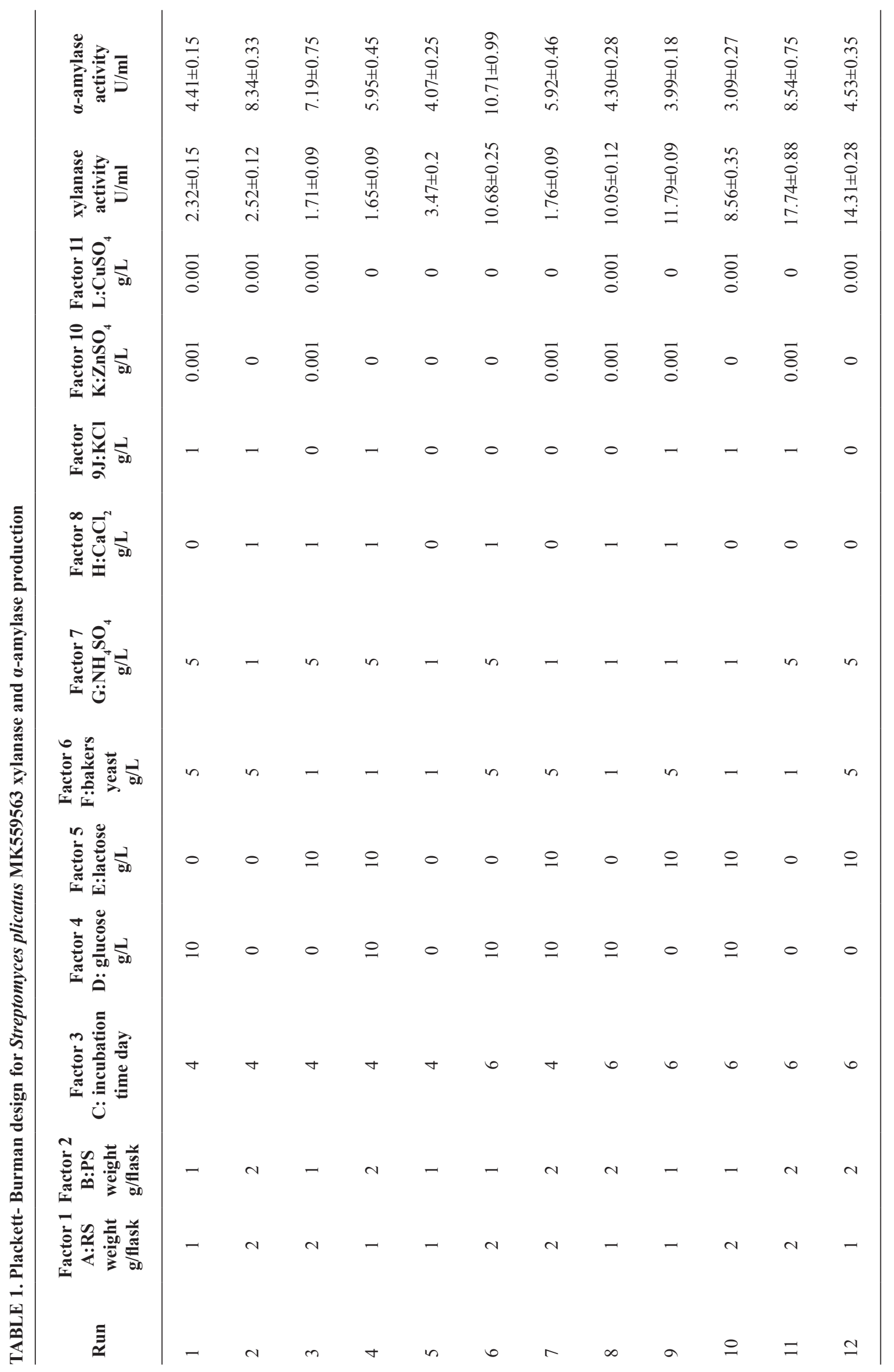

Egypt. J. Microbiol. 55 (2020) 

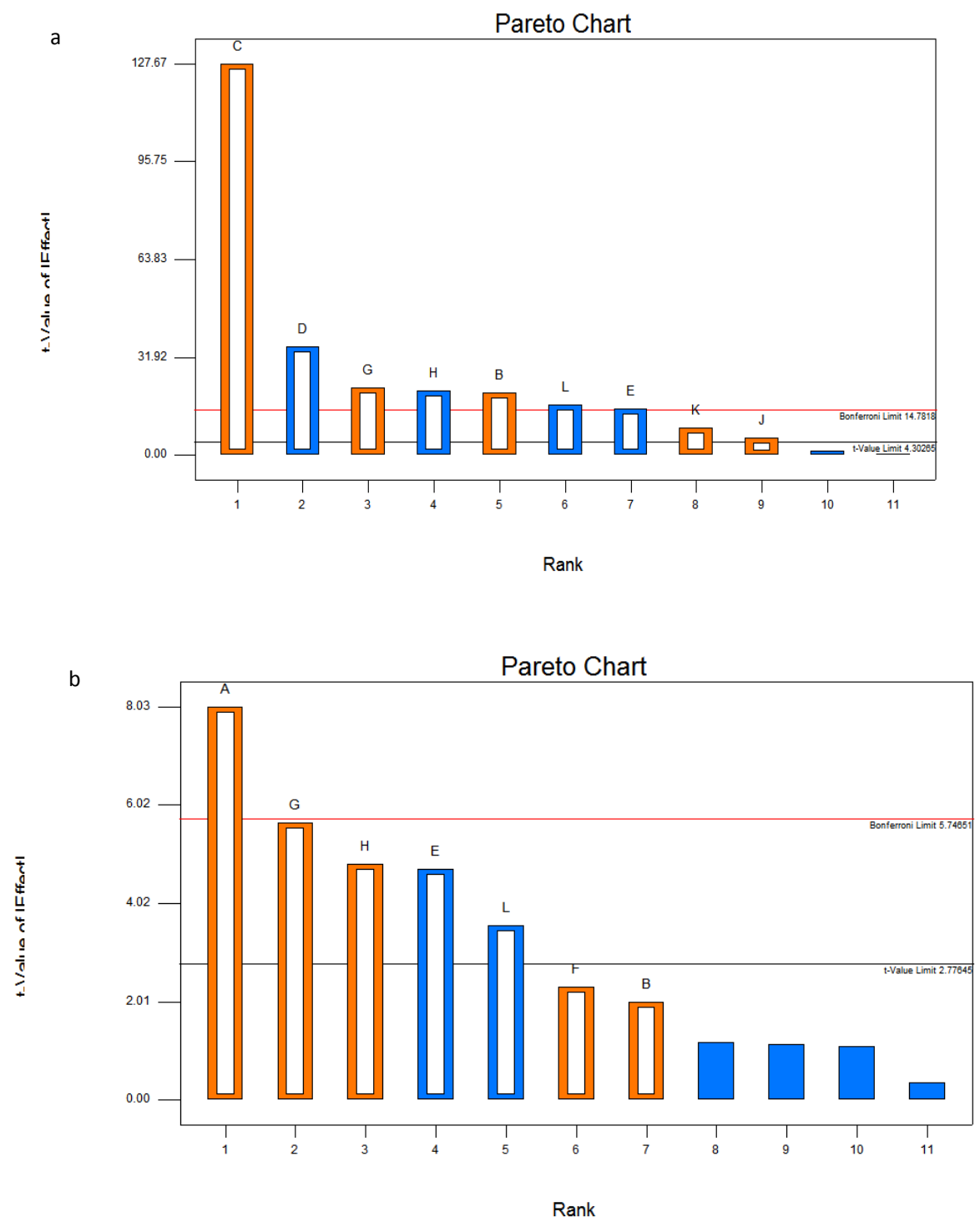

Fig. 3. Pareto chart showing significant variables affecting enzyme production (a, xylanase enzyme production; b, $\alpha$-amylase production)

While for $\alpha$-amylase production only 7 variables exerted a significant effect on enzyme production distinguished into 5 positive variables that exerted enhancement effect (RS weight, $\left(\mathrm{NH}_{4}\right)_{2} \mathrm{SO}_{4} \mathrm{CaCl}_{2}$, baker's yeast, and PS weight) and 2 negative variables (lactose, and $\mathrm{CuSO}_{4}$ ). The enhancement effect of $\mathrm{CaCl}_{2}$ on $\alpha$-amylase production was also reported by Balkan et al. (2011) and Bekler et al. (2019). While, Retnaningrum \& Purwestri (2016) and Hazaa et al. (2018) found $\alpha$-amylase production was enhanced by the addition of, starch and yeast extract as carbon and nitrogen sources, maltose followed by lactose, respectively. In contrast to our study, Hassan \& Abd Karim (2015) reported the enhancement effect of glucose on Bacillus subtilis $\alpha$-amylase production.

The success of the design for Streptomyces plicatus MK559563 xylanase and $\alpha$-amylase production was analyzed by ANOVA as shown in Table 2. Moreover, the success of the design was emphasized by some parameters included $\mathrm{R}^{2}$, adj $\mathrm{R}^{2}$, and pred $\mathrm{R}^{2}$ which were $0.999,0.9994$, and 0.9963 , respectively for xylanase and 0.9762 , 0.9345 , and 0.7855 , respectively for $\alpha$-amylase. As observed the predicated $\mathrm{R}^{2}$ value for both enzymes wa sin reasonable agreement with the adjective $\mathrm{R}^{2}$. 
TABLE 2a. Analysis of variance (ANOVA) for PB designfor Streptomyces plicatus MK559563 xylanase production

\begin{tabular}{|c|c|c|c|c|c|c|}
\hline Source & Sum of squares & df & Mean square & F value & $\begin{array}{l}\text { Pvalue } \\
\text { Prob }>\text { F }\end{array}$ & \\
\hline Model & 355.0713223 & 9 & 39.45236915 & 2164.138 & 0.0005 & Significan \\
\hline B-PS weight & 7.513094584 & 1 & 7.513094584 & 412.1267 & 0.0024 & \\
\hline C-incubation time & 297.1331044 & 1 & 297.1331044 & 16299.08 & $<0.0001$ & \\
\hline D-glucose & 22.73241851 & 1 & 22.73241851 & 1246.975 & 0.0008 & \\
\hline E-lactose & 4.093018081 & 1 & 4.093018081 & 224.5203 & 0.0044 & \\
\hline $\mathrm{G}-\left(\mathrm{NH}_{4}\right)_{2} \mathrm{SO}_{4}$ & 8.80306132 & 1 & 8.80306132 & 482.8872 & 0.0021 & \\
\hline $\mathrm{H}-\mathrm{CaCl}_{2}$ & 7.925433548 & 1 & 7.925433548 & 434.7454 & 0.0023 & \\
\hline $\mathrm{J}-\mathrm{KCl}$ & 0.562429795 & 1 & 0.562429795 & 30.85178 & 0.0309 & \\
\hline $\mathrm{K}-\mathrm{ZnSO}_{4}$ & 1.458585799 & 1 & 1.458585799 & 80.00993 & 0.0123 & \\
\hline $\mathrm{L}_{-} \mathrm{CuSO}_{4}$ & 4.850176308 & 1 & 4.850176308 & 266.0538 & 0.0037 & \\
\hline Residual & 0.036460117 & 2 & 0.018230059 & & & \\
\hline Cor Total & 355.1077824 & 11 & & & & \\
\hline
\end{tabular}

$\mathrm{R}^{2}$ 0.999, adj $\mathrm{R}^{2} \quad 0.9994$ and pred $\mathrm{R}^{2} 0.9963$

TABLE 2b. Analysis of variance (ANOVA) for PB design for Streptomyces plicatus MK559563 a-amylase production

\begin{tabular}{lcccccc}
\hline Source & Sum of squares & df & $\begin{array}{c}\text { Mean } \\
\text { square }\end{array}$ & F value & $\begin{array}{c}\text { P value } \\
\text { Prob>F }\end{array}$ & Significant \\
\hline Model & 57.90416539 & 7 & 8.272024 & 23.40377 & 0.0043 & 0.0013 \\
A-RS weight & 22.79683289 & 1 & 22.79683 & 64.49834 & 0.1168 \\
B-PS weight & 1.406504147 & 1 & 1.406504 & 3.979376 & 0.0092 \\
E-lactose & 7.836676057 & 1 & 7.836676 & 22.17205 & 0.0824 \\
F-baker's yeast & 1.880060558 & 1 & 1.880061 & 5.319194 & 0.0048 \\
G-(NH$)_{2} \mathrm{SO}_{4}$ & 11.28021439 & 1 & 11.28021 & 31.91474 & 0.0085 \\
$\mathrm{H}-\mathrm{CaCl}$ & 8.219541748 & 1 & 8.219542 & 23.25528 & 0.0235 \\
L-CuSO & 4.484335598 & 1 & 4.484336 & 12.68738 & \\
Residual & 1.413793517 & 4 & 0.353448 & & \\
Cor Total & 59.31795891 & 11 & & &
\end{tabular}

$\mathrm{R}^{2} 0.9762$, Pred $\mathrm{R}^{2} 0.9345$ and adj $\mathrm{R}^{2} 0.7855$

Central composite design (CCD) for $S$. plicatus MK559563 xylanase and a-amylase production

CCD for S.plicatus MK559563 xylanase production

In this step, the quantitative effect of the most positive three significant factors incubation time, $\left(\mathrm{NH}_{4}\right)_{2} \mathrm{SO}_{4}$ and PS weight as determined from PB design was tested. As shown in Table 3a, the highest Streptomyces plicatus MK559563 xylanase production $40.65 \mathrm{U} / \mathrm{ml}$ was obtained in the central trials $(2,11,12,13,14$, and 18$)$ causing a 2.30- fold increase in xylanase production compared to the previous step in optimization. Xylanase activity can be calculated from the following equation:
Xylanase activity $=+40.73+1.84 *$ incubation time $+2.13 *\left(\mathrm{NH}_{4}\right)_{2} \mathrm{SO}_{4}-2.16 * \mathrm{PS}$ weight $+0.23 *$ incubation time * $\left(\mathrm{NH}_{4}\right)_{2} \mathrm{SO}_{4}-2.97 *$ incubation time *PS weight $-0.075 *\left(\mathrm{NH}_{4}\right)_{2} \mathrm{SO}_{4} * \mathrm{PS}$ weight $-5.07 *$ incubation time ${ }^{2}-9.33 *\left(\mathrm{NH}_{4}\right)_{2} \mathrm{SO}_{4}{ }^{2}$ $-5.32 *$ PS weight ${ }^{2}$

The interaction between the three variables was shown in Fig. 4a, b, and c. The success of the design was emphasized by statistical analysis (ANOVA) as shown in Table 3b. The model F-value of 91.49 implied the model was significant. Moreover, The values of $\mathrm{R}^{2}(0.9880)$ means that 98.80 of the results can be explained by the design, and pred $\mathrm{R}^{2} 0.9087$ was in reasonable agreement with the adj $\mathrm{R}^{2} 0.9772$. 
TABLE 3a.CCD for Streptomyces plicatus MK559563 xylanase production

\begin{tabular}{|c|c|c|c|c|c|}
\hline \multirow[b]{2}{*}{ Run } & \multirow{2}{*}{$\begin{array}{c}\text { Factor } 1 \\
\text { A: incubation time } \\
\text { days }\end{array}$} & \multirow{2}{*}{$\begin{array}{c}\text { Factor } 2 \\
\text { B:PS weight } \\
\text { g/flask }\end{array}$} & \multirow{2}{*}{$\begin{array}{c}\text { Factor } 3 \\
\mathrm{C:}\left(\mathrm{NH}_{4}\right)_{2} \mathrm{SO}_{4} \\
\mathrm{~g} / \mathrm{l}\end{array}$} & \multicolumn{2}{|c|}{ Xylanase activity $\mathrm{U} / \mathrm{ml}$} \\
\hline & & & & Actual & Predicated \\
\hline 1 & 10 & 2 & 10 & 14.87 & 15.44 \\
\hline 2 & 7 & 3.5 & 6.5 & 40.65 & 40.73 \\
\hline 3 & 7 & 3.5 & 0.61 & 30.66 & 29.32 \\
\hline 4 & 4 & 5 & 10 & 20.85 & 21.81 \\
\hline 5 & 7 & 6.02 & 6.5 & 19.15 & 17.92 \\
\hline 6 & 10 & 5 & 10 & 19 & 20.01 \\
\hline 7 & 7 & 0.98 & 6.5 & 12.44 & 10.74 \\
\hline 8 & 12.04 & 3.5 & 6.5 & 30.25 & 29.49 \\
\hline 9 & 4 & 2 & 3 & 15.33 & 16.38 \\
\hline 10 & 10 & 2 & 3 & 24.44 & 25.54 \\
\hline 11 & 7 & 3.5 & 6.5 & 40.65 & 40.73 \\
\hline 12 & 7 & 3.5 & 6.5 & 40.65 & 40.73 \\
\hline 13 & 7 & 3.5 & 6.5 & 40.65 & 40.73 \\
\hline 14 & 7 & 3.5 & 6.5 & 40.65 & 40.73 \\
\hline 15 & 1.95 & 3.5 & 6.5 & 25.45 & 23.29 \\
\hline 16 & 7 & 3.5 & 12.39 & 23.66 & 22.07 \\
\hline 17 & 10 & 5 & 3 & 30.15 & 30.42 \\
\hline 18 & 7 & 3.5 & 6.5 & 40.65 & 40.73 \\
\hline 19 & 4 & 2 & 10 & 16.35 & 18.15 \\
\hline 20 & 4 & 5 & 3 & 18.85 & 20.34 \\
\hline
\end{tabular}

TABLE 3b. Analysis of variance (ANOVA) for CCD for S.plicatus MK559563 xylanase production

\begin{tabular}{|c|c|c|c|c|c|c|}
\hline Source & $\begin{array}{l}\text { Sum of } \\
\text { squares }\end{array}$ & df & $\begin{array}{l}\text { Mean } \\
\text { square }\end{array}$ & F value & $\begin{array}{l}\text { P value } \\
\text { Prob }>\text { F }\end{array}$ & \\
\hline A- incubation time & 46.32498 & 1 & 46.32498 & 19.21638 & 0.0014 & Significant \\
\hline B-PS weight & 62.19742 & 1 & 62.19742 & 25.80053 & 0.0005 & \\
\hline $\mathrm{C}-\left(\mathrm{NH}_{4}\right)_{2} \mathrm{SO}_{4}$ & 63.60405 & 1 & 63.60405 & 26.38402 & 0.0004 & \\
\hline $\mathrm{AB}$ & 0.41405 & 1 & 0.41405 & 0.171755 & 0.6873 & \\
\hline $\mathrm{AC}$ & 70.44845 & 1 & 70.44845 & 29.2232 & 0.0003 & \\
\hline $\mathrm{BC}$ & 0.045 & 1 & 0.045 & 0.018667 & 0.8940 & \\
\hline $\mathrm{A}^{\wedge} 2$ & 370.6616 & 1 & 370.6616 & 153.7566 & $<0.0001$ & \\
\hline $\mathrm{B}^{\wedge} 2$ & 1255.454 & 1 & 1255.454 & 520.7835 & $<0.0001$ & \\
\hline $\mathrm{C}^{\wedge} 2$ & 407.1786 & 1 & 407.1786 & 168.9045 & $<0.0001$ & \\
\hline Residual & 24.10703 & 10 & 2.410703 & & & \\
\hline Lack of Fit & 24.10703 & 5 & 4.821406 & & & \\
\hline Pure Error & 0 & 5 & 0 & & & \\
\hline Cor Total & 2009.106 & 19 & & & & \\
\hline
\end{tabular}



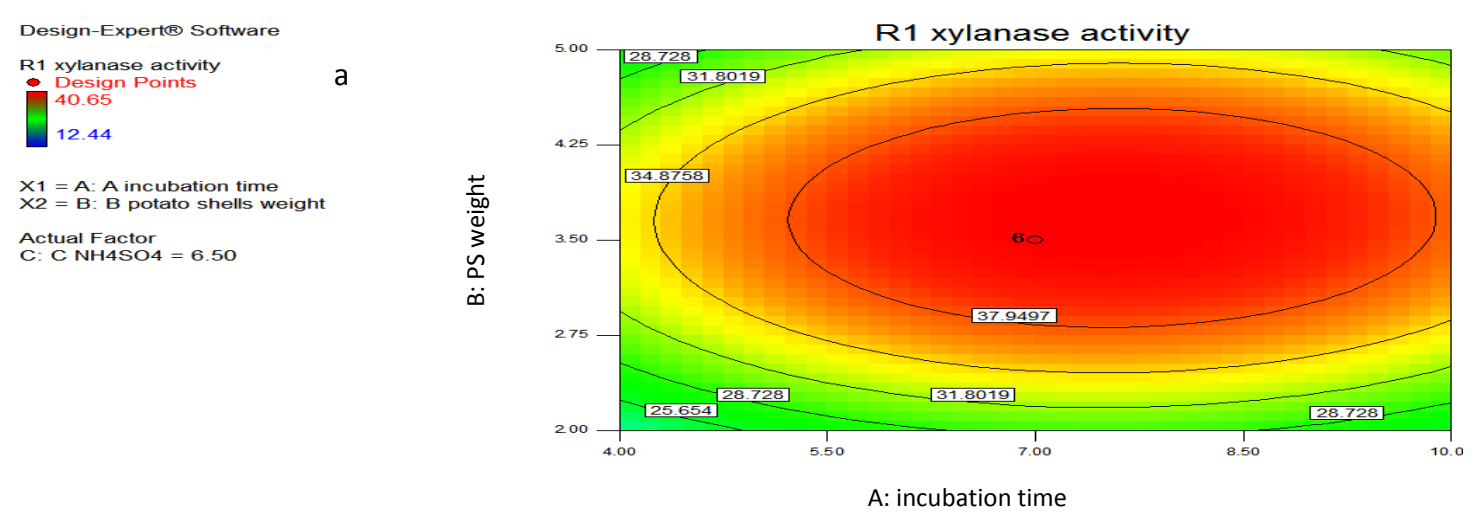

Design-Experteo Software

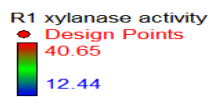

b

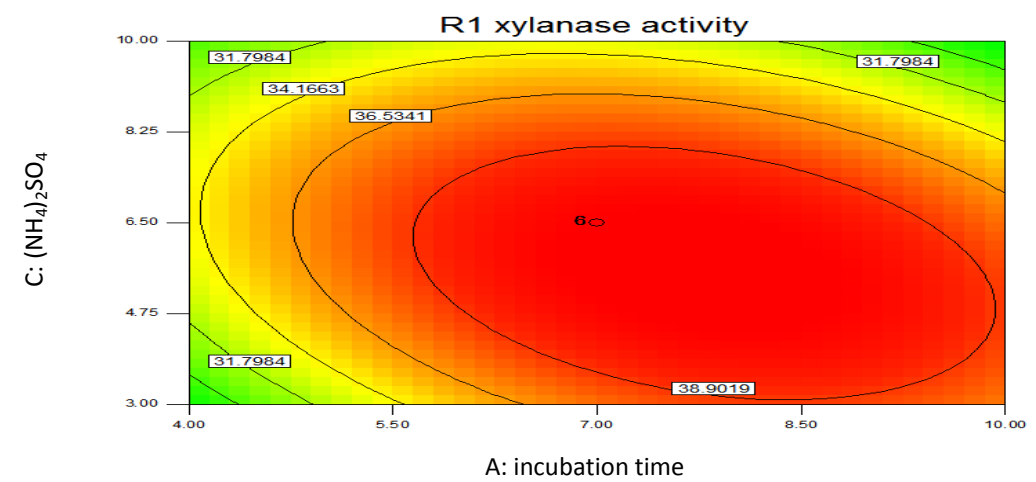

Design-Expert@ Software

R1 xylanase activity

Design Points

$\mathrm{X} 1=\mathrm{A}:$ A incubation time
$\mathrm{X} 2=\mathrm{C}: \mathrm{C}$ NH4SO 4

Actual Factor

a

$=\mathrm{B} \cdot \mathrm{B}$ potato shells weigh X2 $=$ C: $\mathrm{C}$ NH4SO4

Actual Factor

A: A incubation time $=7.00$

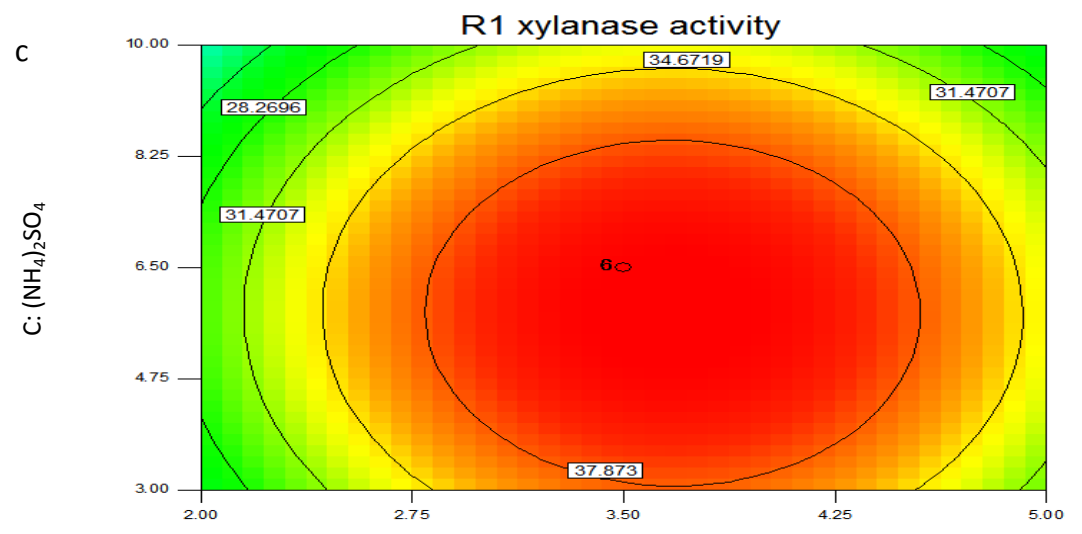

B: PS weight

Fig. 4. Contour plot showing an interaction between, a: Incubation time and PS weight when $\left(\mathrm{NH}_{4}\right)_{2} \mathrm{SO}_{4}$ was kept at optimum concentration $6.50 \mathrm{~g} / \mathrm{L}$; b: Incubation time and $\left(\mathrm{NH}_{4}\right)_{2} \mathrm{SO}_{4}$ when PS weight was kept at optimum concentration 3.5g/flask; c: PS weight and $\left(\mathrm{NH}_{4}\right)_{2} \mathrm{SO}_{4}$ when the incubation time was maintained at optimum value 7 days

CCD for S. plicatus MK559563 a-amylase production

For $\alpha$-amylase production, the quantitative effect of RS weight, $\left(\mathrm{NH}_{4}\right)_{2} \mathrm{SO}_{4}$ and $\mathrm{CaCl}$ was examined. As shown in Table 4a. The highest Streptomyces plicatus MK559563 $\alpha$-amylase production of $33.85 \mathrm{U} / \mathrm{ml}$ was obtained in central trials $1,3,6,15,16$, and 20 causing 3.16- fold increase compared to the previous step of optimization. Our result was higher than that reported by Božić et al. (2011), Pathania et al. (2017) and Kwatia et al. (2017).

The $\alpha$-amylase activity can be calculated from the following equation :

$\alpha$-amylase activity $=+33.86+3.52 * \mathrm{RS}$

weight $+3.05 *\left(\mathrm{NH}_{4}\right)_{2} \mathrm{SO}_{4}+0.48 * \mathrm{CaCl}_{2}-3.57$

$* \mathrm{RS}$ weight $*\left(\mathrm{NH}_{4}\right)_{2} \mathrm{SO}_{4}+4.61 * \mathrm{RS}$ weight

$* \mathrm{CaCl}_{2}+2.44 *\left(\mathrm{NH}_{4}\right)_{2} \mathrm{SO}_{4} * \mathrm{CaCl}_{2}-3.20 * \mathrm{RS}$ weight ${ }^{2}-6.01 *\left(\mathrm{NH}_{4}\right)_{2} \mathrm{SO}_{4}-1.77 * \mathrm{CaCl}_{2}^{2}$ 
TABLE 4a. CCD for $S$. plicatus MK559563 $\alpha$-amylase production

\begin{tabular}{|c|c|c|c|c|c|}
\hline \multirow{2}{*}{ Run } & \multirow{2}{*}{$\begin{array}{c}\text { Factor } 1 \\
\text { A: RS weight } \\
\text { g/flask }\end{array}$} & \multirow{2}{*}{$\begin{array}{c}\text { Factor } 2 \\
\text { B: }\left(\mathrm{NH}_{4}\right)_{2} \mathrm{SO}_{4} \\
\mathrm{~g} / \mathrm{l}\end{array}$} & \multirow{2}{*}{$\begin{array}{c}\text { Factor } 3 \\
\text { C: CaCl } \\
\text { g/l }\end{array}$} & \multicolumn{2}{|c|}{$\alpha$-amylase activity $\mathrm{U} / \mathrm{ml}$} \\
\hline & & & & Actual & Predicated \\
\hline 1 & 3.5 & 6.5 & 6.5 & 33.85 & 33.85 \\
\hline 2 & 5 & 10 & 10 & 33.75 & 33.4 \\
\hline 3 & 3.5 & 6.5 & 6.5 & 33.85 & 33.85 \\
\hline 4 & 3.5 & 0.61 & 6.5 & 12.35 & 11.72 \\
\hline 5 & 2 & 10 & 3 & 28.55 & 11.72 \\
\hline 6 & 3.5 & 6.5 & 6.5 & 33.85 & 33.85 \\
\hline 7 & 3.5 & 12.39 & 6.5 & 21.66 & 21.98 \\
\hline 8 & 5 & 3 & 3 & 24 & 24.26 \\
\hline 9 & 5 & 10 & 3 & 17.44 & 18.34 \\
\hline 10 & 6.02 & 6.5 & 6.5 & 31.76 & 30.72 \\
\hline 11 & 3.5 & 6.5 & 0.61 & 28.45 & 29.55 \\
\hline 12 & 2 & 3 & 3 & 18.75 & 19.31 \\
\hline 13 & 2 & 10 & 10 & 24.33 & 24.28 \\
\hline 14 & 0.98 & 6.5 & 6.5 & 18.15 & 18.88 \\
\hline 15 & 3.5 & 6.5 & 6.5 & 33.85 & 33.85 \\
\hline 16 & 3.5 & 6.5 & 6.5 & 33.85 & 33.85 \\
\hline 17 & 5 & 3 & 10 & 28.45 & 29.55 \\
\hline 18 & 3.5 & 6.5 & 12.39 & 29.55 & 29.65 \\
\hline 19 & 2 & 3 & 10 & 6.85 & 6.16 \\
\hline 20 & 3.5 & 6.5 & 6.5 & 33.85 & 33.85 \\
\hline
\end{tabular}

TABLE 4b. Analysis of variance (ANOVA) forCCD for Streptomyces plicatus MK559563 a-amylase production

\begin{tabular}{lcccccc}
\hline Source & $\begin{array}{c}\text { Sum of } \\
\text { squares }\end{array}$ & df & $\begin{array}{c}\text { Mean } \\
\text { square }\end{array}$ & F value & $\begin{array}{c}\text { P value } \\
\text { Prob>F }\end{array}$ \\
\hline Model & 1251.566 & 9 & 139.0629 & 228.0257 & $<0.0001$ & Significant \\
A-RS weight & 169.0525 & 1 & 169.0525 & 277.2007 & $<0.0001$ & $<0.0001$ \\
$\mathrm{~B}^{-}\left(\mathrm{NH}_{4}\right)_{2} \mathrm{SO}_{4}$ & 127.1899 & 1 & 127.1899 & 208.5572 & 0.0483 \\
$\mathrm{C}-\mathrm{CaCl}_{2}$ & 3.084146 & 1 & 3.084146 & 5.057172 & $<0.0001$ \\
$\mathrm{AB}$ & 101.8165 & 1 & 101.8165 & 166.9516 & $<0.0001$ \\
$\mathrm{AC}$ & 170.0168 & 1 & 170.0168 & 278.7819 & $<0.0001$ \\
$\mathrm{BC}$ & 47.72645 & 1 & 47.72645 & 78.25856 & $<0.0001$ \\
$\mathrm{~A}^{\wedge} 2$ & 147.7369 & 1 & 147.7369 & 242.2489 & $<0.0001$ \\
$\mathrm{~B}^{\wedge} 2$ & 520.9776 & 1 & 520.9776 & 854.2633 & \\
$\mathrm{C}^{\wedge} 2$ & 45.2343 & 1 & 45.2343 & 74.1721 & \\
Residual & 6.09856 & 10 & 0.609856 & & \\
Lack of Fit & 6.09856 & 5 & 1.219712 & & \\
Pure Error & 0 & 5 & 0 & & & \\
Cor Total & 1257.664 & 19 & & &
\end{tabular}


The interaction between the three variables was shown in Fig. 5a, b, and c. The success of the design was emphasized by statistical analysis (ANOVA) as shown in Table 4b. The model F-value of 228.03 implied the model was significant. Moreover, The values of $\mathrm{R}^{2}$ (0.9952) means that 99.52 of the results can be explained by the design, andpred $\mathrm{R}^{2} 0.9604$ was in reasonable agreement with the adj $\mathrm{R}^{2} 0.9908$.

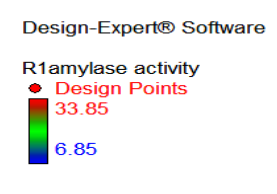

$\mathrm{X} 1=\mathrm{A}:$ : rice straw weight
$\mathrm{X} 2=\mathrm{B}: \mathrm{B}$ NH4SO4 Coded Factor C. $\mathrm{C} \mathrm{CaCl}=0.000$

Design-Expert(e) Software

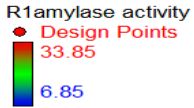

$\mathrm{X} 1=\mathrm{A}: \mathrm{A}$ rice straw weight $\mathrm{X} 2=\mathrm{C}: \mathrm{C} \mathrm{CaCl}$

Coded Factor

B: $\mathrm{B}$ NH4SO4 $=0.000$ a

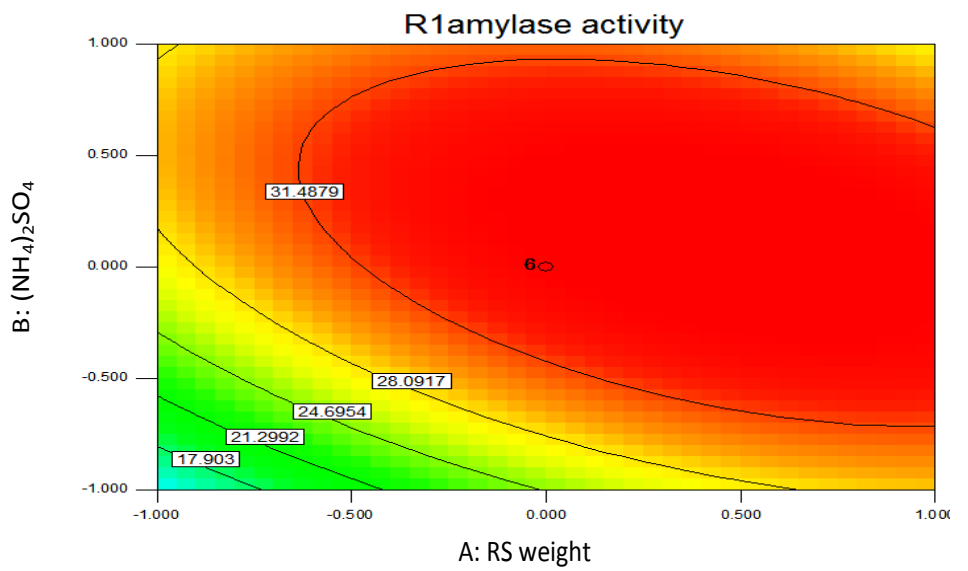

b

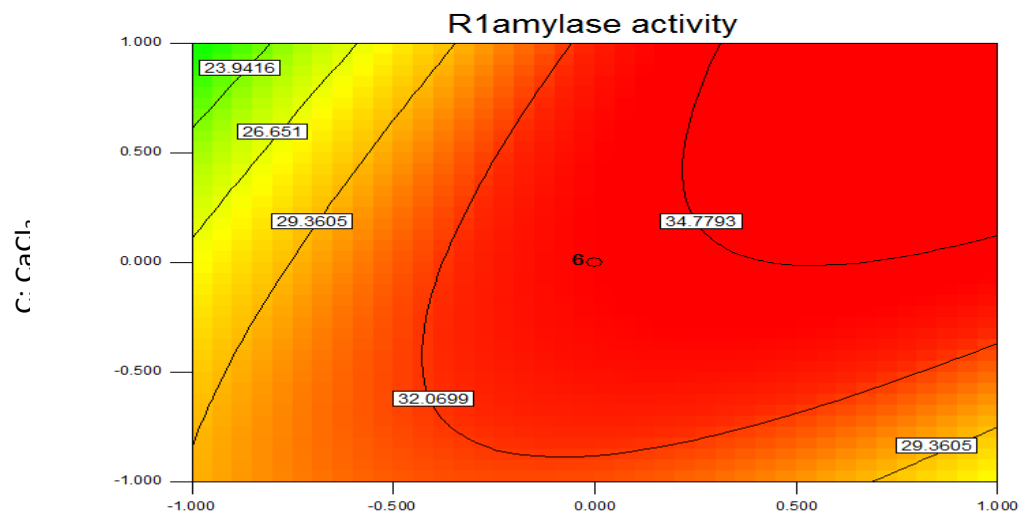

A: RS weight

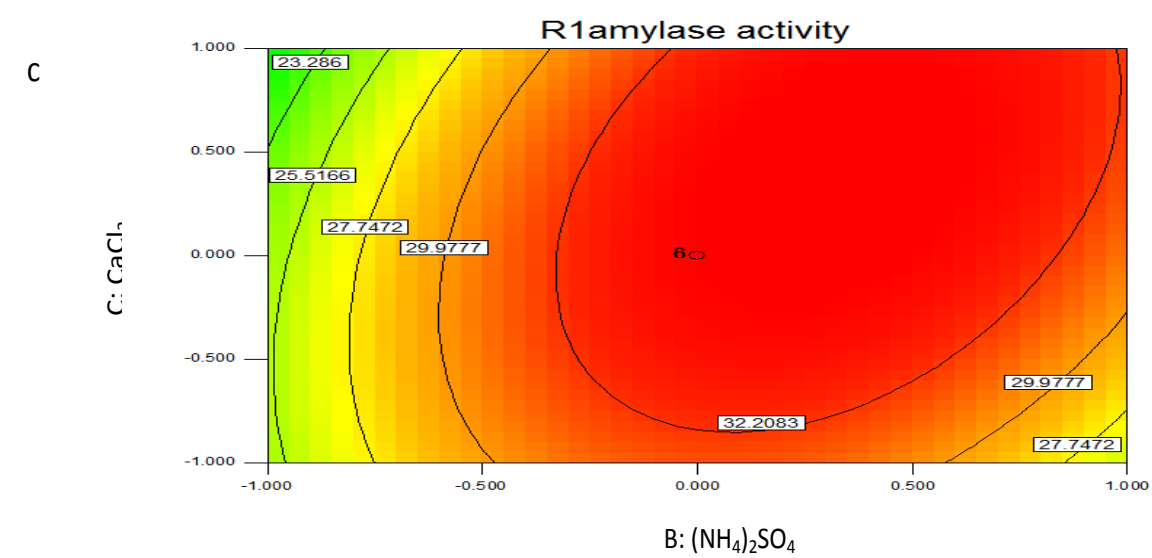

B: $\left(\mathrm{NH}_{4}\right)_{2} \mathrm{SO}_{4}$

Design-Expert(B) Software

6.85

$\times 1=\mathrm{B}: \mathrm{B} \mathrm{NH} 4 \mathrm{SO}_{4}$
$\times 2=\mathrm{C}: \mathrm{C} \mathrm{CaCl}$

Coded Factor
A: A rice straw weight $=0.000$

Fig. 5. Contour plot showing an interaction between, a: $\mathrm{RS}$ weight and $\left(\mathrm{NH}_{4}\right)_{2} \mathrm{SO}_{4}$ weight when $\mathrm{CaCl}_{2}$ was kept at zero levels $(6.5 \mathrm{~g} / \mathrm{L})$; $\mathrm{b}$ : $\mathrm{RS}$ weight and $\mathrm{CaCl}_{2}$ when $\left(\mathrm{NH}_{4}\right)_{2} \mathrm{SO}_{4}$ was kept at zero levels $(6.5 \mathrm{~g} / \mathrm{L})$; $\mathrm{c} \mathrm{CaCl}_{2}$ and $\left(\mathrm{NH}_{4}\right)_{2} \mathrm{SO}_{4}$ when $\mathrm{RS}$ weight was maintained at zero levels $(3.5 \mathrm{~g} / \mathrm{flask})$ 


\section{Conclusion}

The industrially potent enzymes xylanase and $\alpha$-amylase can be produced with low cost and the eco-friendly environmental method by the use of soil isolate Streptomyces plicatus MK559563. That was capable of producing xylanase and $\alpha$-amylase by the SmFtechnique utilizing RS and PS as substrates. Streptomyces plicatus MK559563 xylanase and $\alpha$-amylase production werestatistically optimized through two designs Plackett-Burman (PB) and Central composite design (CCD). The highest S. plicatus MK559563 xylanase production $(40.65 \mathrm{U} / \mathrm{ml})$ was obtained in media composed of $\mathrm{g} / \mathrm{L}$ : Baker's yeast (1), $\left(\mathrm{NH}_{4}\right)_{2} \mathrm{SO}_{4}(6.5), \mathrm{KCl}(1), \mathrm{ZnSO}_{4}$ (0.001) with RS ( $2 \mathrm{~g} /$ flask) and PS (3.5 g/flask) for 7 days of incubation. The highest $\alpha$-amylase production was obtained in mediacomposed of $\mathrm{g} / \mathrm{L}$ : Glucose (10), baker's yeast (5), $\left(\mathrm{NH}_{4}\right)_{2} \mathrm{SO}_{4}(6.5), \mathrm{CaCl}_{2}$ (6.5) with RS (3.5 g/flask) and PS (1g/flask) for 6 days of incubation.

Acknowledgments: The authors are sincerely thankful to the Microbiology Department, Faculty of Science, Ain Shams University and National Research Centre, the Chemistry of Natural and Microbial Products Department.

Conflict of interest: The authors declare that there is no conflict of interest.

\section{References}

Abd El Aty, A.A., Saleh, S.A.A., Eid, B.M., Ibrahim, N.A., Mostafa, F.A. (2018) Thermodynamics characterization and potential textile applications of Trichoderma longibrachiatum KT693225 xylanase. Biocataly. Agric. Biotechnol. 14, 129137.

Ahmed, S.A., Saleh, S.A.A., Mostafa, F.A., Abd ElAty, A.A., Ammar, H.A.M. (2016) Characterization and valuable applications of xylanase from endophytic fungus Aspergillus terreus KP900973 isolated from Corchorus olitorius. Biocataly. Agric. Biotechnol. 7, 134-144.

Ali, M.B., Irshad, M., Anwar, Z., Zafar, M., Imran, M. (2016) Screening and statistical optimization of physicochemical parameters for the production of xylanases from agro-industrial wastes. Advances in Enzyme Research, 4, 20-33.
Balkan, B., Balkan, S., Ertan, F. (2011) Optimization of parameters for $\alpha$-amylase production under solid-state fermentation by Trichothecium roseum. Romanian Biotechnological Letters, 16(5), 65916600 .

Bekler, F.M., Yalaz, S., Güven, R.G. (2019) Optimization of the thermostable alkaline and $\mathrm{Ca}$ dependent $\alpha$-amylase production from Bacillus paralicheniformis by statistical modeling. J. Serb. Chem. Soc. 84(0), 1-13.

Bernard, B. (2007) Access excellence @ the national health museum, Isolation of Antibiotic Strinas from Soils. (www. access excellence. org.) July.

Bhushan, S., Kalia, K., Sharma, M., Singh, B., Ahuja, P.S. (2008) Processing of apple pomace for bioactive molecules. Crit. Rev. Biotechnol. 28, 285-296.

Biely, P. (1985) Microbial xylanolytic systems. Trends Biotechnol. 3, 286-290.

Božić, N., Ruiz, J., López-Santín, J., Vujčić, Z. (2011) Optimization of the growth and $\alpha$-amylase production of Bacillus subtilis IP 5832 in shake flask and laboratory fermenter batch cultures. $J$. Serb. Chem. Soc. 76(7), 965-972.

Brzezinski, R., Dery, C.V., Beaulieu, C. (1999) Thermostable xylanase DNA, protein and methods in use," USA patent 5871730, 1999.

Chen, X.S., Tang, L., Li, S., Liao, L.J., Zhang, J.H., Mao, Z.G. (2011) Optimization of medium for enhancement of epsilon-Poly-L-Lysine production by Streptomyces sp. M-Z18 with glycerol as carbon source. Bioresour. Technol. 102, 1727-1732.

Cui, F., Zhao, L. (2012) Optimization of xylanase production from Penicilliumsp.WX-Z1 by a twostep statistical strategy: Plackett-Burman and BoxBehnken experimental design. Int. J. Mol. Sci. 13, 10630-10646.

Cui, F.J., Liu, Z.Q., Li, Y., Ping, L.F., Ping, L.Y., Zhang, Z.C., Lin, L., Dong, Y., Huang, D.M. (2010) Production of mycelial biomass and exo-polymer by Hericium erinaceus CZ-2: optimization of nutrients levels using response surface methodology. Biotechnol. Bioproc. 15, 299-307. 
Daneault, C., Leduc, C., Valade, J.L. (1994) The use of xylanases in kraft pulp bleaching-A review. Tappi J. 77, 125-131.

Das, M., Gupta, S., Kapoor, V., Banerjee, R., Bal, S. (2008) Enzymatic polishing of rice-A new processing technology. Lwt-Food Sci. Technol. 41, 2079-2084.

Diaz, A.B., Bolivar, J., de Ory, I., Caro, I., Blandino, A. (2011) Applicability of enzymatic extracts obtained by solid state fermentation on grape pomace and orange peels mixtures in must clarification. $L w t$ Food Sci. Technol. 44, 840-846.

Hang, Y.D., Woodams, E.E. (1997) Xylanolytic activity of commercial juice-processing enzyme preparations. Lett. Appl. Microbiol. 24, 389-392.

Hassan, H., Abd Karim, K. (2015) Optimization of alpha amylase production from rice straw using solid-state fermentation of Bacillus subtilis. Internat. J. Sci. Environment Technol. 4(1), 1-16.

Hayakawa, M., Nonomura, H. (1987) Humic acidvitamin agar, a new medium for the selective isolation of soil actinomycetes. J. Fermen. Technol. 65(5), 501-509.

Hazaa, M.M., Sabae, S.Z., Areej, I. F. T., Eldourghamy, A.S., Sayed, H. (2018) Production, purification and characterization of alfa-amylase produced by bacteria from pharaonic lake. J. Basic Environmental Sciences, 5, 162-173.

Kwatia, S., Dzogbefia, V.P., Ofosu, I.W. (2017) Optimization of amylase production by Aspergillus niger cultivated on yam peels in solid state fermentation using response surface methodology. Afr. J. Biochem. Res. 11(7), 34-42.

Liu, B.L., Tzeng, Y.M. (1998) Optimization of growth medium for production of spores from Bacillus thuringiensis using response surface methodology. Bioprocess Eng. 18, 413-8.

Locci, R. (1989) Streptomycetes and related genera. In: "Bergey's Manual of Systematic Bacteriology", Williams, S.T., Sharpe, M.E., Holt, J.G. (Eds.), pp. 2451-93. Baltimore: Williams and Wilkins.

Mohamed, S.H., Seham, S.D.E.H., Mona, A.I., Sadik, A.S. (2013) Taxonomy of Streptomyces strains isolated from rhizospheres of various plant species grown in Taif region, KSA, having antagonistic activities against some microbial tissue culture contaminants. Afr. J. Biotechnol. 12(14), $1657-$ 1664.

Mohamed, Sonya H., Omran, W.M., Sadik, A.S. (2014) Use of 16S rRNA gene for molecular identification of some bacteria isolated from soil in Taif having biochemical and antibiosis activities. Wulfenia $J$. 21(2), 173185.

Nawani, N., Aigle, B., Mandal, A., Bodas, M., Ghorbel, S., Prakash, D. (2013) Actinomycetes: Role in biotechnology and medicine. Bio. Med. Res. Int. Special Issue 2013.

Pandey, A., Nigam, P., Soccol, C.R., Soccol, V.T., Singh, D., Mohan, R. (2000) Advances in microbial amylases. Biotechnol. Appl. Biochem. 31, 135-152.

Parajó, J.C., Domínguez, H., Domínguez, J. (1998) Biotechnological production of xylitol. Part 1: Interest of xylitol and fundamentals of its biosynthesis. Bioresourc. Technol. 65, 191-201.

Pathania, S., Sharma, N., Handa, S. (2017) Optimization of culture conditions for production of amylase by bacillus amyloliquifacienssh8 using response surface methodology. Proc. Indian Natn. Sci. Acad. 83(1), 203-210.

Periyasamy, A.K., Muthu, M., Kannan, V. (2010) Optimization of nutrients for the production of RNase by Bacillus firmus VKPACU1 using response surface methodology. Biotechnol. Bioprocess, 14, 202-206.

Plackett, R.L., Burman, J.P. (1946) The design of optimum multifactorial experiments. Biometrika, 37, 305-325.

Polizeli, M.L.T.M., Rizzatti, A.C.S., Monti, R., Terenzi, H.F., Jorge, J.A., Amorim, D.S. (2005) Xylanases from fungi: Properties and industrial applications. Appl. Microbiol. Biotechnol. 67, 577-591.

Puspitasari, F., Nurachman, Z., Noer, A.S., Radjasa, O.K., Maarel, M., Natalia, D. (2011) Characteristics of raw starch degrading amylase from Bacillus aquimarisMKSC 6.2 associated with soft coral Sinularia sp. Starch. 63, 461- 467.

Retnaningrum, E., Purwestri, Y.A. (2016) Molecular identification and optimization culture conditions

Egypt. J. Microbiol. 55 (2020) 
of amylase producing bacteria isolated from green algae in the coast side of southern sea, Yogyakarta, Indonesia. AIP Conference Proceedings, 1755(1), $8 \mathrm{p}$.

Sajjad, M., Choudhry, S. (2012) Effect of starch containing organic substrates on alpha amylase production in Bacillus strains. Afr. J. Microbiol. Res. 6(45), 7285-7291.

Salihu, A., Alam, M.Z., AbdulKarim, M.I., Salleh, H.M. (2011) Optimization of lipase production by Candida cylindracea in palm oil mill effluent based medium using statistical experimental design. J. Mol. Catal. Enzym. 69, 66-73.

Sathyar, R., Ushadevi, T. (2014) Industrially important enzymes producing Streptomyces species from mangrove sediments. Internat. J. Pharmacy Pharmaceut. Sci. 6(10), 233-237.

Sharma, A., Satyanarayana, T. (2013) Microbial acid-stable $\alpha$-amylases: characteristics, genetic engineering and applications. Proc. Biochemi. 48, 201-211.

Sivaramakrishnan, S., Gangadharan, D., Kesavan, M.N., Ricardo, S.C., Pandey, A. (2006) $\alpha$-amylases from microbial sources - An overview on recent developments. Food Technol. Biotechnol. 44, 173184.

Soleimani, M., Tabil, L., Panigrahi, S., Alberta, E. (2006) Bio-production of a Polyalcohol (Xylitol) from Lignocellulosic Resources: A Review written for presentation at the CSBE/SCGAB 2006 Annual Conference, Society; 2006.

Somogyi, M.J. (1952) Notes on sugars determinations. J. Biol. Chem. 195, 19-23.
Subramaniyan, S., Prema, P. (2002) Biotechnology of microbial xylanases: Enzymology, molecular biology, and application. Critical Rev. Biotechnol. 22, 33-64.

Syed, D.G., Agasar, D., Pandey, A. (2009) Production and partial purification of $\alpha$-amylase from a novel isolate Streptomyces gulbargensis. J. Ind. Microbiol. Biotech. 36(2), 189-194.

Sykes, G., Skinner, F.A. (1973) "Actinomycetales: Characteristics and Practical Importance". Academic Press. London. 339p.

Verma, D., Kanagaraj, A., Jin, S.X., Singh, N.D., Kolattukudy, P.E., Daniell, H. (2010) Chloroplastderived enzyme cocktails hydrolyse lignocellulosic biomass and release fermentable sugars. Plant Biotechnol. J. 8, 332-350.

Viikari, L., Kantelinen, A., Sundquist, J., Linko, M. (1994) Xylanases in bleaching: From an idea to the industry. FEMS Microbiol. Rev. 13, 335-350.

Vurukonda, S.S.K.P., Giovanardi, D., Stefani, E. (2018) Plant growth promoting and biocontrol activity of Streptomyces spp. as endophytes. Internat. J. Molecular Sci. 19, 1-26.

Wang, H.Y., Fan, B.Q., Li, C.H., Liu, S., Li, M. (2011) Effects of rhamnolipid on the cellulase and xylanase in hydrolysis of wheat straw. Bioresour. Technol. 102, 6515-6521.

Warzywoda, M., Ferre, V., Pourquie, J. (1983) Development of culture medium for large-scale production of cellulytic enzymes by Trichoderma reesei. Biotechnol. Bioeng. 25, 3005-3011. 


\section{التحسين الأحصائى لأنتاج إنزيمات الزيلينيز والألفا أميليز الصناعية بواسطة Streptomyces plicatus MK559563 على مخلفات زراعية.}

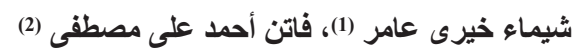

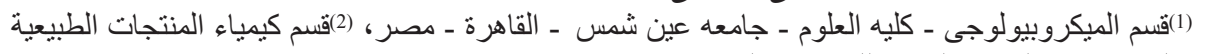

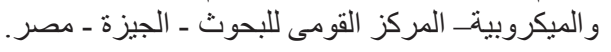

نجح Streptomyces plicatus MK559563 المعزول من التربة في إنتاج مركبات مهمة مثل السكريات

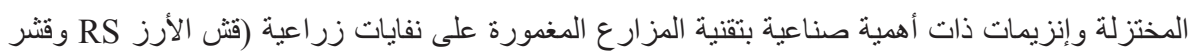

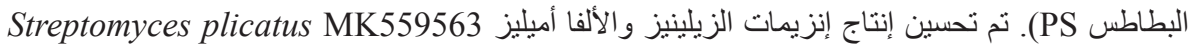

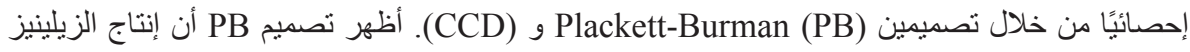

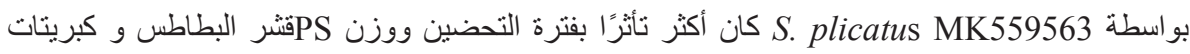

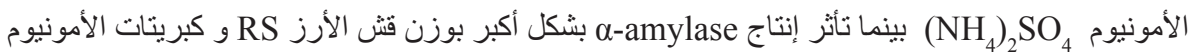

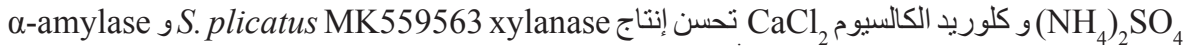
بنسبة 39.69 و 61.60 ضعفًا بواسطة النظام الأحصائى المحسنة لإنتاج Sylanase

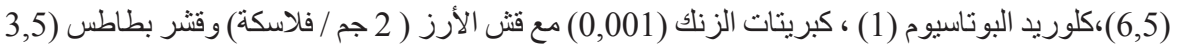
جم / فلاسكة) لمدة 7 أيام من التحضين. الوسائط الئحسَّنة لإنتاج الألفا

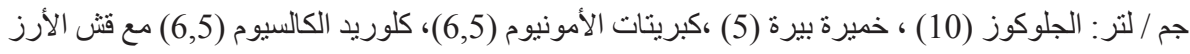

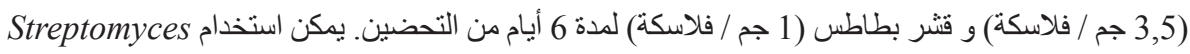

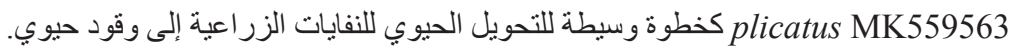

